\title{
Characteristics of Forest Fires and their Impact on the Environment
}

\author{
László FÖLDI, ${ }^{1}$ Rajmund KUTI ${ }^{2}$
}

\begin{abstract}
We can hear about large scale forest fires in the media from several areas of the European Union almost every year. A large forest fire causes a serious impact on the environment, determining its future for decades. Prevention of forest fires is one of today's most important tasks as well as appropriate preparedness for effective fighting against them. To do so, it is vital to have detailed knowledge on the characteristics of different forest types and their environment, their ecosystems and foodchains, and technical information on the properties of forest fires and their effects on the different elements of the environment and lessons learned from previous cases. Based on gathered information of past events authors have provided a complete system of forest fire categories by their size, type, risks and consequences. We investigated the detailed impacts of forest fires on the different elements of the environment.

The content of this paper may help the work of the sylviculturists and other agrarian experts involved in the rehabilitation processes of forest ecosystems after largescale forest fires.
\end{abstract}

Keywords: ecosystem, environment, fire-fighting, forest fire

\section{Introduction}

The number of forest fires due to climate change is continuously growing nowadays. With the expansion of the European Union (EU from now on) appropriate defence against forest fires becomes more and more important. The number of annual forest fires within the EU is between 50-70 thousand, touching 3-5 thousand square kilometres and causing damages in millions of Euros. It was recognized by environmental experts of the EU that forest fires cause significant ecological, economic and social problems in many European countries with possible long term consequences to the natural environment and the economy. [1] Member states of the EU have created common directives ${ }^{3}$ and national regulations for the protection of forests and prevention of forest fires and carry on different scientific research in this topic. [2] Planning of environmental security has become a primary task. [3] Investigation of forests' structures, proper knowledge on the development of forest fires and their impact on the environment can help in the protection against forest fires and in fighting against large scale forest fires, which is a complex and difficult task for defence organizations and personnel. [4] [5]

1 Associate professor, National University of Public Service, Faculty of Military Sciences and Officer Training; e-mail: foldi.laszlo@uni-nke.hu

2 Assistant professor, University of West Hungary, Faculty of Agricultural and Food Sciences

3 Council regulation (EEC) NO 3529/86 on protection of the community's forests against fire 


\section{Reasons of Forest Fires}

When drought causes dryness, or after every large scale forest fire the attention turns to the forests, to the investigation of natural fires' prevention, fire-fighting, its technical and organizational issues and the reasons and consequences of forest fires.

Forests can be divided into 3 categories by the types of their trees and undergrowth: [5]

- deciduous forest (oak, beech, poplar trees);

- coniferous forest (pine trees, juniper bushes);

- mixed forest (mixture of deciduous and coniferous species).

The fires' ignition and spreading parameters of forest types are different. Undergrowth of a deciduous forest has more humidity in general, so it does not catch fire easily. But there is a high resin content in the leaves and trunks of coniferous trees causing easier kindling and burning. These forests are dryer, in general. Approximately $75 \%$ of forest fires happen in pine woods and only $25 \%$ in deciduous forests. [5] Concerning the reasons and consequences of forest fires the following categories can be investigated in details:

- abiotic factors;

- biotic factors;

- economic factors;

- human factors.

Abiotic factors: From the elements of the climate, the amount of precipitation and the temperature are the key components in the development of forest fires. Additional parameters can be:

- amount of daily sunlight;

- atmospheric circumstances;

- prevailing wind speed and wind direction.

Relief forms on the surface are also important, because fires in general can rapidly spread from lower terrains uphill. Also ragged surface with rifts, rocks or watercourses can stop vegetation fires.

Biotic factors: Populations of species and interactions among the individuals are the key aspects during forestation to select proper tree species. It is especially important in our country to handle coniferous species with care, because they are affected with fires the most, and have influence on the range and seriousness of forest fires.

Age of forests, quality and quantity of undergrowth and thickness of dead fallen leaves are also important biotic factors.

Economic factors: Environmentally friendly, secure and responsible sylviculture plays an important role, because it has a great role in minimizing development and spread of forest fires. Neatness of forests, clearness of forest passes, tracts and trenches are also important, because forests become more opened and transparent this way. [6]

Woodcutting and burning of cutting waste also affect forest fires. Regulated and sustainable economics is important, [29: para 2] together with the observation of rules and capabilities for effective fire-fighting.

Human factors: One of the most common reasons of forest fires is inappropriate human activity. Most of the forest fires start because of human faults, carelessness or intentional fire-raising. 
Most common human activities causing forest fires:

- forbidden or irregular firing;

- growing tourism by car or motorcycle;

- smoking in forests;

- burning of agricultural waste or stubble in the vicinity of forests.

\section{Categories of Forest Fires}

Forest fires can be divided into 4 categories in the forests of Hungary based on tree and other vegetation species:

- underground burning, peat fire;

- fire in undergrowth or dead fallen leaves;

- fire in seedlings and saplings;

- fire in trunks and shrouds.

\section{Underground Burning}

Underground burning can start in forests, where peat layers can be found beneath. In most cases under-composed organic material enriched in the upper layers of soil burns without flames. These types of fires are rare, but when they happen, they can last long and can spread onto large territories. Their spreading speed is very slow, some centimetres or maximum a few meters per day. Reasons can be self-ignition or fire in undergrowth.

\section{Fire in Undergrowth}

Flames spread directly on the surface vegetation (dry grass, dead fallen leaves, twigs, etc.) burning the lower parts of the trunks and roots above the surface. Fires in undergrowth can be divided into 3 categories based on their spreading speed ( $\mathrm{Vt}$ ) and flame height $(\mathrm{Hf})$ :

- week, if $V t \leq 1 \mathrm{~m} / \mathrm{min}$ and $H f \leq 0.5 \mathrm{~m}$;

- moderate, if $V t \leq 1-3 \mathrm{~m} / \mathrm{min}$ and $H f \leq 0.5-1.5 \mathrm{~m}$;

- strong, if $V t>3 \mathrm{~m} / \mathrm{min}$ and $H f>1.5 \mathrm{~m}$. [5]

The spreading speed greatly depends on wind speed and wind direction. Spreading in the wind direction is 6-10 times quicker than in headwind.

Based on their duration we can distinguish running fires and persistent fires. Running fires burn down the dry vegetation close to the surface. Plants with higher water content and deeper, humid soil layers are not affected. Running fires can be formed by high wind speeds and spread rapidly.

Persistent fires in undergrowth spread slowly because of a low wind speed and not only surfaces are burned, but fires also spread in the upper mould layers with glow and dense smoke. Skins and roots of trees are also heavily damaged during these types of fires and small seedlings, saplings and bushes burn totally. Persistent fires in undergrowth can spread even onto the trunks and shrouds of larger trees. 


\section{Fire on Seedlings and Saplings}

In case of persistent fires in undergrowth, additionally smaller trees, bushes can catch fire. In sapling areas of forests in the presence of heavy winds spreading speeds can reach 500 meters per hour. In most cases spreading has an irregular form; the burned area grows radially. [5]

\section{Fire on Trunks and Shrouds}

During dry or drought periods, fires in undergrowth can grow to fires on trunks and even on shrouds. Their common feature is that fire spreads not only on the ground, but on trunks, leaves and shrouds of bushes and trees, with the burning of leaves, twigs and bigger arms of the trees. As a consequence, trees die in most cases.

Additional fire in undergrowth can be formed during fires in shrouds, this time the burning of undergrowth is part of the shroud fire. Three categories can be described based on horizontal speed of fire spreading $(V t)$ : [7]

- week, if $V t<3 \mathrm{~m} / \mathrm{min}$;

- moderate, if $3 \leq V t \leq 10 \mathrm{~m} / \mathrm{min}$;

- strong, if $V t>10 \mathrm{~m} / \mathrm{min}$.

Based on their behaviour in time it can be also divided into two groups: running and persistent shroud fires. A running shroud fire can be formed in case of a heavy, stormy wind. Spreading of fire happens with "jumps" among shrouds this way being far ahead of the accompanying undergrowth fire. In general, the fire starts within the undergrowth, than lower parts of the shrouds heat up, begin to burn, and the fire spreads in the shrouds by the help of the wind.

In case of persistent shroud fires, they spread among the shrouds, but the ground surface burns down, too. They can be formed with weak winds. After this kind of fire trees are heavily burned, charred, and can fall down.

When grouping forest fires, we have to make differentiation based on the types of affected territories. Because of their different features, we can talk about forest fires on plains and in mountain areas. Forest fires in mountains are extremely dangerous, because of the high resin content of coniferous trees the speed of spreading can be 2-3 times quicker than in deciduous forests.

Fighting against forest fires in mountains can be more difficult because of the rough terrain and rare water sources.

\section{Size of Forest Fires}

Forest fires can also be categorized by their sizes, based on the affected areas. In general, the territories of forests are greater in mountains and hills than in marshy plains. We can talk about:

- small forest fire, if size smaller than 1 hectare;

- average, if size between 1 and 50 hectares;

- large, if size greater than 50 hectares.

The following graphics (Graph 1) shows the relative numbers, based on the data of different sized forest fires from the last 10 years in Hungary. 


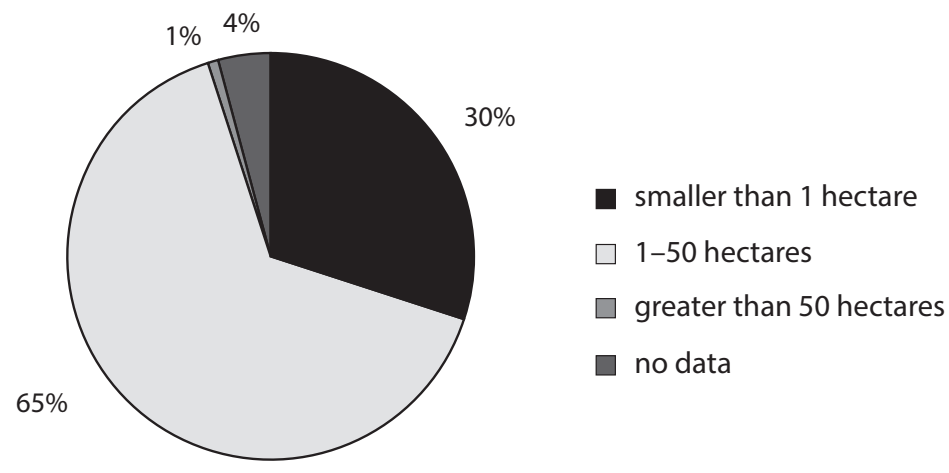

Graph 1. Sizes of forest fires in Hungary.

(Source: based on the data of NFCSO, ${ }^{4}$ completed by the authors.)

\section{Effects of Forest Fires to the Environment}

\section{Effects of Forest Fires to the Movements of Air}

Differences in air pressures between geographical points are equalized by significant and continuous movements of air. [8] This movement shows a form of unperturbed flow in the absence of external effects. A forest is an obstacle, so the moving air changes its direction and form after a collision.

It can be observed on the windward side of the forest that wind blows through the fringe of the forest depending on the wind speed, the density of the forest and the surface relief. If the wind direction is perpendicular to the fringe of the forest, it always blows through a larger area. On the opposite side of the forest, a shadow zone can be observed, where the air movement is less intense. Its size depends on many factors, in general 6-10 times larger than the effected forest area. Wind speed beyond the shadow zone is equal with its speed in front of the forest. [9]

In addition to the above mentioned effects, the surface relief, large objects on the ground, vegetation, effects of large fires, and other factors can disturb the unperturbed wind flow resulting in whirling movements. This is the so called "turbulence" that has significant effects on the use of fire-fighting aircraft in low altitudes in case of forest fires, and on the spreading of smoke.

Mechanical turbulence. Unevenness in the shroud level of the forest, cuttings, clearings and the fringe of the forest together force the disturbed air into a whirly movement with horizontal axis. These mechanical turbulences in low altitudes can cause danger to the fire-fighting aircrafts, but their predictable presence and moderate airflows allow the pilots to handle them securely. [10]

4 National Food Chain Safety Office; official website: www.nebih.gov.hu 


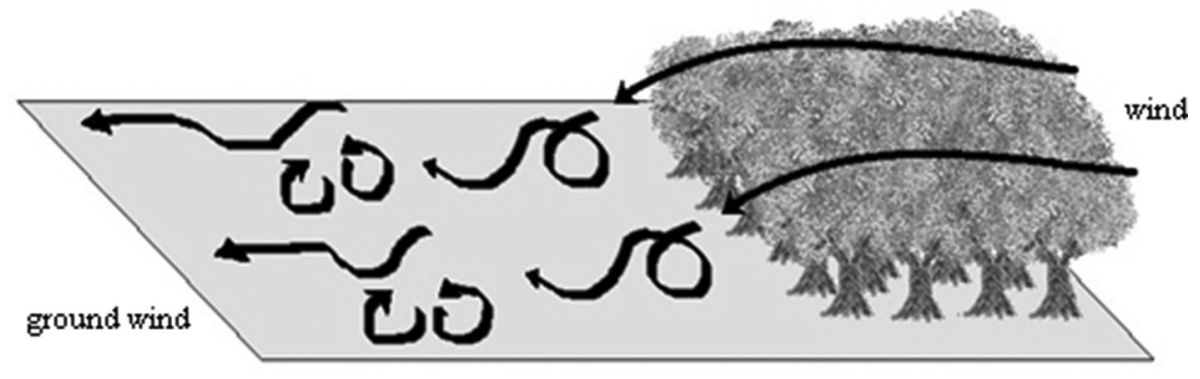

Figure 1. Formation of mechanical turbulence.

(Source: based on the work of Á. Restás [10: 48], completed by the authors.)

Thermic turbulence. Because of vertical temperature differences in the atmosphere the pressure difference causes an airflow blowing vertically upwards in a spiral, whirly movement. The speed of the vertical wind depends on the temperature gradient.

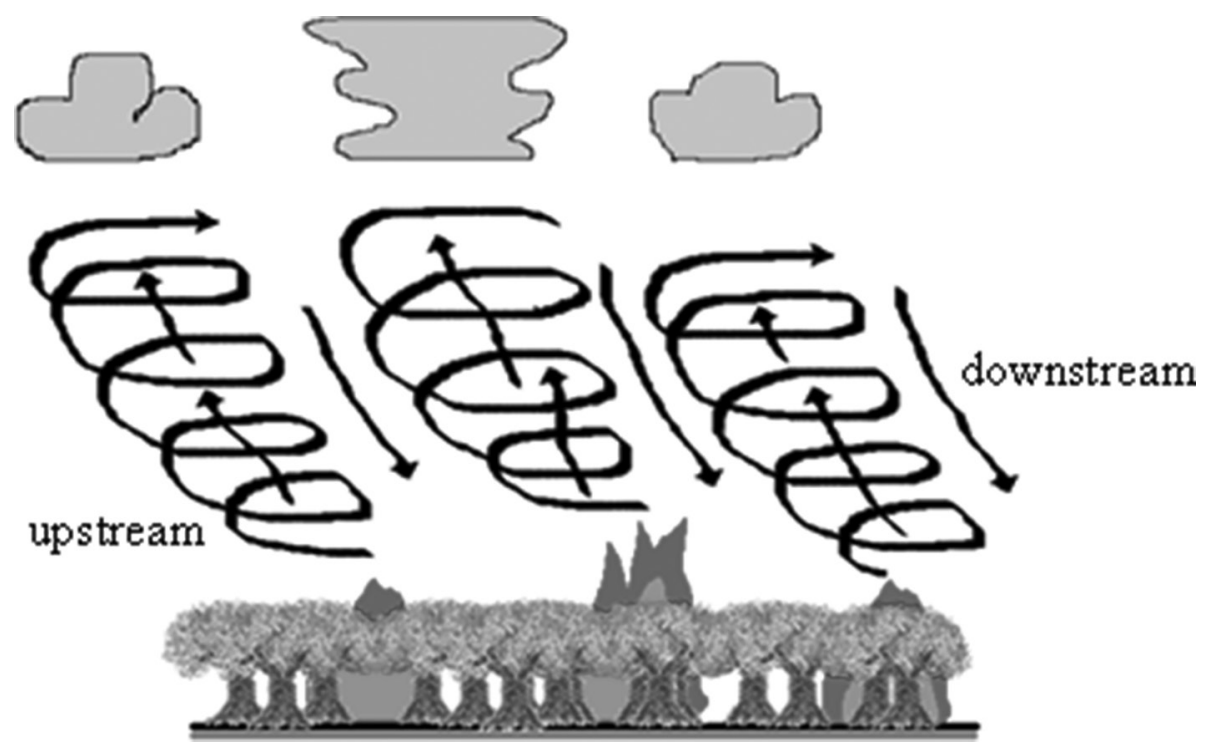

Figure 2. Streams of thermic turbulence.

(Source: based on the work of Á. Restás [10: 49], completed by the authors.)

Calculation of the energy of thermic turbulence is difficult. In general, it is very dynamic, able to change its direction very quickly and it is very unpredictable. Intensive upstreams can be accompanied by nearby downstreams with the same intensity. Between the very intensive upstreams and downstreams the so called "wind openings" can be formed. This is extremely dangerous for fire-fighting aircrafts! If the forms of upstreams and downstreams are visible (smoke), their areas must be evaded during the flight both towards the target and in the opposite way. The only advantage of the intensive airflows is that together with the hot air it also transports the smoke. This way we can collect more accurate data during air reconnaissance about the place, size and behaviour of the fire, and less smoke means better sight in general. 
Mixture of mechanical and thermic turbulences. The above described types of turbulences do not come up in their pure forms in case of a forest fire due to the presence of wind. By the combined effect of wind and fire the mixture of the two types and its separation for different zones can be observed. Because of the unpredictability of the instantaneous movements of turbulent airflows low altitude flights with fire-fighting aircrafts can become very risky and only the experience of the pilots can help to compensate this.

Formation of bubbles. In case of no wind, with the development of a forest fire, a very unique type of airflow can be observed. Heated air over the fire forms a bubble and lifts from the surface as a big ball without developing a continuous airflow. Cold air replaces the bubble; it is also heated quickly and goes up in the same way. This is a rapid procedure repeating with a pulse.

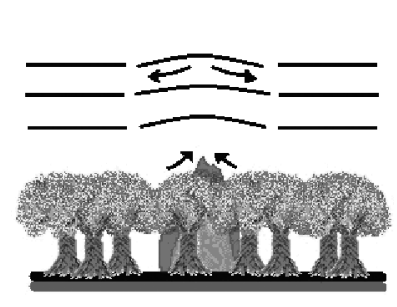

beginning phase

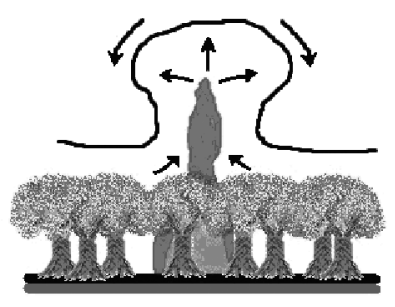

rise of a bubble

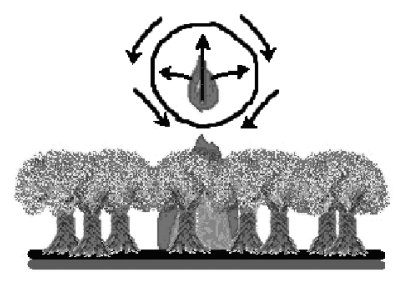

split of a bubble

Figure 3. Phases of bubble formation.

(Source: based on the work of Á. Restás [10: 49], completed by the authors.)

The forming bubble looks like the smoke puffing up from a steam locomotive. Danger of the bubbles comes from their sudden formation and termination. In one moment circumstances can be ideal to fly over the flames with a fire-fighting aircraft while some seconds later nothing can be seen because of the heavy smoke.

\section{Environmental Hazards of Forest Fires}

Environmental hazards of forest fires must be investigated in order to prevent further fires, to develop appropriate techniques for fire-fighting and for the proper restoration of damaged, burned forest areas after forest fires. [5] In the following we will describe the harmful effects of forest fires on different elements of the environment in a timely manner.

Either the fire is natural or man-made; it can disturb and strongly change the structures and functional processes of forest ecosystems. Consequences of fires are hard to describe in general, because they are functions of their characteristics. Some of these are: frequency of their repetition in time, volume of fires, their intensity (fire on dead fallen leaves, on shrubs or on the tree-tops) and duration, in which season were they occurred, climatic circumstances during fires and precipitation intensity before and after the fires.

Forest fires can have very serious economic and environmental impacts. There are different ways to measure the economic impact; [11] [12] [13] however measuring the environmental impact is very difficult.

Environmental impact of forest fires can be categorized in many ways. Classification is important, because certain harms could be prevented together in the future with the use of 
a common method by the recognition of similarities. The base of the classification can be their duration, the size of threatened territory, their harmful effects on the vegetation, animal kingdom, soil, air, water or other distinguished categories.

\section{Vegetation}

One of the reasons of raising frequency and seriousness of forest fires is the desiccation process emanating from "global climate change”. [14] As a consequence of this desiccation process, the amount of annual precipitation in Hungary decreased by approximately 100 millimetres in the last 4-5 years. [15] The humidity of plants has also decreased, and this resulted in a lower flash-point of the vegetation. Resistance of species is different; some plants are regenerating faster after a forest fire and so will spread on larger territories than before. [16] Vegetation species that cannot regenerate themselves must be replanted to restore ecological balance in the forest. [17]

Effects on boreal plants. Fires have less intensity on parklands mostly with frondiferous trees and bushes, where burnable, dry material is in a lesser amount so burning can be only partial on plants and on the terrain. This means that one part of the branches of trees and bushes survives while the other falls because of the heat stress. These trees and bushes have a chance to regenerate depending on the damage cropping up from their trunks, branches, sprigs, stumps or roots. Forest parts dense in pine-tree and juniper are more sensitive to fire and can strongly feed it. The fire can grow tall here quickly causing total destruction. Tinetrees and junipers totally burn away together with other neighbouring frondiferous trees, bushes and perpetuals. Perpetuals, frondiferous trees and bushes living together with junipers burn more or less, and in the vicinity of heavily burning junipers they can suffer total burning destruction, so all their parts above the ground are damaged by the fire. After the fire the environment is lifeless for a year. Then different apexes, sprits start to grow very quickly and in a large amount, the area grows green proving the surviving and renewing capability of nature even after a fire catastrophe. Rejuvenation of the vegetation, natural greening of the burned terrain can happen also with seeds. Seeds can survive fires in the soil or can come from neighbouring territories with the wind, or by the birds, insects or other animals. Sprits and apexes of some plants fruit soon and producing lots of seeds to ensure their proliferation. Pines however cannot regenerate after heavy burning, their rejuvenation comes very slowly with their seeds only, and so settling them back needs human help.

Effects on non-boreal (herbaceous) plants. Herbaceous plants are necessary to cover and protect soil. After a fire, rejuvenation of the vegetation, growing of plants start only next spring. For the meantime soil remains uncovered so the Sun can burn, the wind can dry and rain can degrade it. This way remaining minerals from burned plants and part of the degraded topsoil can lapse to lower grounds to produce very favouring production environment there.

Herbaceous plants after a fire are regenerated in a vegetative way, with turions. Appearance of turions is very spectacular in a year. Every plant after a fire, even those species which are unwanted at the given ecosystem are completing a very important protection task. In their presence, the young, 1-2 years old arboreals together with surviving seeds and others from neighbouring territories can breed and settle back. So herbaceous plants are indispensable to cover and protect topsoil. 


\section{Animals}

Direct effects of fires on animals can be:

- fires can destroy animals living on the territory;

- fires can change ecological features of the biotope this way becoming unsuitable for species living there before but helping to settle new species with different demands.

Extent of direct destruction effect for different species depends on their position in the zootaxy. In general the greater, quick moving mammals and birds can escape successfully to safer grounds. So their destruction rate is low, only younger, weaker ones die, but the young of birds nesting on the ground are heavily affected. Mortality is much greater within smaller or slow moving animals such as frogs, lizards, snails, spiders. Forest fires can cause dramatic destruction among their populations. Soil surprisingly has a good heat insulation effect, so ant-hills and larviforms of insects growing in the ground generally survive forest fires.

Indirect effects of fires, elimination or damage of animal biotopes cause more obvious, permanent changes in forest fauna. The reason is that most of animal species have greater specific demands concerning their biotopes than we can estimate based upon our first investigation of a forest environment.

Resistance of the fauna species is only limited by their escape capabilities and this depends on the spreading speed of the fire. In case of a high speed running fire even quicker, larger animals cannot escape. In general, nests and animal hideouts are totally destroyed in burned areas. This drives the local fauna to migration. Because of the destroyed vegetation and the replaced fauna, the balance of the micro environment upsets, and the local natural environment changes. [18]

\section{Soil}

Erosion of the soil speeds up after a forest fire due to partially or totally destroyed vegetation, the upper fertile soil layer can disappear. [19] [20] In absence of the cohesion power of fibrous root systems soil becomes loose and washable. [21] [22] After a forest fire soil can easily and quickly be washed by rains from hillsides. On plains, ash layers generated by the fire can be washed from the surface into the deep soil making the soil alkaline that leads to the extinction of plants that cannot tolerate alkalinity. [23] [24] A further problem is that the heat generated by the fire kills microorganisms useful to plants, so replacement of vegetation becomes slower.

Due to burning and scorching of seeds rejuvenation of the flora is only possible with newly arriving seeds into the soil. Those plants that cannot tolerate alkalified soil will die in a short time. This harm will be one of the obstacles against the restoration of the original ecosystem. The origin of the tree species is indifferent in the formation of the soil fauna diversity. The layer of the dead fallen leaves above the populations and physical-chemical parameters of the soil are more important. In general, populations of some natural, native soil fauna species are richer in numbers (in number of individuals and number of species also) than fauna of regenerated soils after forest fires.

An additional consequence of forest fires is that soil erosion can speed up due to partly or totally destroyed flora, this way topsoil can be heavily degraded or totally eliminated. After burning the parts of the plants above the ground fire does not stop, it slowly destroys in brand 
form even the roots, underground parts. This way the soil cohesion force of the roots disappears and soil becomes easily washable. This problem typically exists in mountain areas.

Materials used for fire-fighting or possibly applied fire retardants, foams can penetrate into the soil and change the original balancing chemical processes in it, this way causes acidification or alkalization and changes the soil's chemical composition. These features of fire-extinguishing materials were not investigated, because in the development phase their primary use was not planned in a natural environment. We do not know all the environmental impacts of these chemicals in details, although they are called "chemically natural”, they will change natural chemical composition ratios in the soil. For example, artificial acidification can mobilize heavy metal salts in underground water, which were insoluble in natural circumstances before. Thus heavy metals can be incorporated into the plants and get into the food chains.

\section{Atmosphere}

A large amount of organic micro particles in the atmosphere emanating from incomplete burning can pollute the air. During forest fires, huge quantities of carbon dioxide $\left(\mathrm{CO}_{2}\right)$ go into the atmosphere aggravating the growing tendencies of the greenhouse effect accelerating global warming. [25] Because of forest fires, territories of woodlands and an amount of trees reduce together their photosynthetic performance and oxygen production, making the situation even worse. [26] Due to incomplete burning carbon monoxide (CO) also goes into the atmosphere causing serious health risks to animals and fire-fighters.

With the burning of vegetation additional toxic products of combustion are formed and enter the atmosphere in a large amount. Such chemicals are the different volatile oils, benzene and its derivatives that come out during burning and decomposition of wooden materials. As the burning is incomplete, a lot of remaining organic micro particles in the air also pollute the atmosphere. These micro particles form during the partial breakdown of organic materials. These air pollutants are dangerous and harmful not only at the site of the forest fire and its vicinity, but can be transported with the air movements generated by the fire (mentioned before) to longer distances and higher altitudes. Reaching some kilometres of altitude these chemicals can be transmitted 50-100 kilometres and spread pollution into distant territories. [5]

\section{Water}

Forest fires have direct and indirect pollution effects on waters due to the harmful chemicals formed by fires first going into the atmosphere later to the waters by precipitation or sedimentation. Ash, scale and small plant pieces can cause direct surface pollution in nearby waters. Indirectly, the pollution can spread longer distances by the wind polluting distant waters. [27] [28]

Water used for fire-fighting can wash other fire extinguishing chemicals into the neighbouring surface waters, polluting rivers and lakes in the vicinity. Those chemicals that are neutral in soil and only change the chemical composition ratio but are otherwise inactive, can be activated in water by a series of chemical reactions, causing dangerous pollution on much larger territories e.g. alongside a river. These pollutants can endanger or even exterminate water ecosystems. Due to suddenly spreading, large amounts of water used in fire-fighting 
(especially from air), water balance of the territory collapses, biological balance of natural surface and underground waters tumbles down, animals and vegetation rarify due to rapid modification of living conditions, in the worst case life perishes from the area.

\section{Beneficial Environmental Effects of Forest Fires}

Surprisingly, forest fires have some beneficial effects on the environment and to the development of forest ecosystems. It must be emphasized that these are only minor benefits, they exist only from a certain point of view and cannot be compared with the serious negative consequences mentioned before.

Such a benefit is, for example, that the life cycle of some plant species needs repetitive forest fires. Fir-cones of some pine-trees of North America and Europe open only in extreme heat caused by the fire and spread their seeds only in that case. These pine species have strong, thick barks efficiently resisting the fire so forest fires are integral parts of their reproduction process.

Another interesting fact is that frequent forest fires are parts of the reproduction process of some animals and insects also. Larviforms of some insects under the barks of trees can be born only in case of a fire; otherwise they are waiting in pupation form for years.

After a forest fire there is a chance to force back unwanted plant species using conscious methods of forestry.

Another beneficial consequence of forest fires is that burned remnants of vegetation remain on site. Partly degraded organic materials enter the food chain for later utilization as ingredients of rejuvenated vegetation. This way organic materials remain in the recycling process. So only the bigger parts of trees must be transported from the site, small pieces must remain for further utilization as biomass for nature's benefit.

\section{Results}

We described effects and consequences of forest fires to forest ecosystems and environmental elements in our paper. It was ascertainable that ruined vegetation and rarefied animal species will cause a collapse in the micro environmental balance and in the food chain. Fire will block and set back regeneration processes. The balancing, life giving and biotope protecting role of the forest will disappear, losses will be serious because of the devastation of biotopes. It is obvious, that harm and negative effects of forest fires will be similar to the whole environment in a larger scale.

We managed to find some beneficial consequences of forest fires also, but they are negligible compared to environmental harm.

We found direct correlation between meteorological extremities being stronger in the last 10 years, decreasing amount of precipitation, higher average temperatures and winters without snowfalls and the increased amount of forest fires in Hungary and within the EU. 80-90\% of these fires are caused by human activities, a smaller number is caused by extreme weather phenomena, mainly by lightning. Similarly to other forest protection problems prevention would be the cheapest, most effective solution in case of forest fires, but in parallel with this, we should be well prepared also for efficient fire-fighting and proper handling of caused environmental damages. 
In our opinion most of the consequences of forest fires will be revealed only after a longer period of time, and in many cases burned territories can only partly be regenerated or damage could become permanent.

Everyone knows that we need forests in the future, so we described ecological and other damage caused by forest fires. Protection of our forests has a paramount importance, so we must act quickly and effectively to defend them, especially against those want to harm them.

\section{References}

[1] FÖLDI L., HALÁSZ L.: Környezetbiztonság. Budapest: Complex Kiadó, 2009.

[2] NAIR, P. K.: Agroforestry Systems and Environmental Quality: Introduction. Journal of Environmental Quality, 403 (2011), 784-790. DOI: https://doi.org/10.2134/jeq2011.0076

[3] YAN, Q. L., ZHU, J. J., HU, B., SUN, O. J.: Environmental impacts of shelter forests in Horquin Sandy Land, China. Journal of Environmental Quality, 403 (2011), 815-824.

[4] MOLNÁR G.: Katasztrófák. Budapest: Szövetkezeti Szervezési Iroda, 1991.

[5] NAGY D.: Erdőtüzek megelőzési és oltástechnológiai lehetőségeinek vizsgálata. Sopron: Nyugat-magyarországi Egyetem, 2008. (PhD-értekezés)

[6] SZOTT, L. T., CASS, D. C. L.: Fertilizers in agroforestry systems. Agroforestry Systems, 23 (1993), 157-173.

[7] BLESZITY J., ZELENÁK M.: A túzoltás taktikája. Budapest: BM Könyvkiadó, 1989.

[8] SANCHEZ, P. A.: Science in agroforestry. Agroforestry Systems, 30 (1995), 5-55.

[9] RESTÁS Á.: Mikro-meteorológiai tényezők a légi tűzoltásban. (Micro-meteorological factors of the aerial firefighting.) Védelem, 95 (2002), 17-19. http://vedelem.hu/letoltes/ ujsag/v200205.pdf (downloaded: 1010 2015)

[10] RESTÁS Á.: Az erdőtüzek légi felderítésének és oltásának kutatás-fejlesztése. Budapest: Zrínyi Miklós Nemzetvédelmi Egyetem, 2008. (PhD-értekezés)

[11] GOULD, J., PLUCINSKI, M., McCARTHY, G., HOLLIS, J., HANDMER, J., GANEWATTA, G.: Effectiveness and efficiency of aerial fire-fighting in Australia. Fire Note, 5011 (2009).

[12] RESTÁS Á.: Theoretical approaches for evaluating the economic efficiency of the aerial firefighting helping strategic planning. In. VIEGAS, D. X., RIBEIRO L. M.: Advances in Forest Fire Research. (1900-1910.), Coimbra: Universidade de Coimbra, 2014.

[13] RESTÁS Á.: Az erdőtűzoltás hatékonyságának közgazdasági megközelítése. (Economic approaching of the effectiveness of fighting forest fire.) Védelem, 185 (2011), 47-50.

[14] ABU-ZREIG, M., RUDRA, R. P., WHITELEY, H. R., LALONDE M. N., KAUSHIK, N. K.: Phosphorus removal in vegetated filter strips. Journal of Environmental Quality, 32 (2003), 613-619. DOI: https://doi.org/10.2134/jeq2003.0613

[15] ISAAC M. E., KIMARO, A. A.: Diagnosis of nutrient imbalances with vector analysis in agroforestry systems. Journal of Environmental Quality, 40 (2011), 860-866.

[16] HOWLETT, D. S., MOSQUERA-LOSADA, M. R., NAIR, P. K. R., RIGUEIRORODRIGUEZ, A.: Soil carbon storage in silvopastoral systems and a treeless pasture in northwestern Spain. Journal of Environmental Quality, 40 (2011), 825-832.

[17] KORT, J., POPPY, L., GORDON, A. M., CARON, L. (Eds.): Temperature agroforestry: When trees and crops get together. Agriculture, Ecosystems and Environment, 131 (2009), $1-2$. 
[18] MOSER, E. B., SAXTON, A. M., PEZESHKI, S. R.: Repeated measures analysis of variance: Application to tree research. Canadian Journal of Forest Research, 20 (1990), 524-535. DOI: https://doi.org/10.1139/X90-069

[19] BRONICK, C. J., LAL, R.: Soil structure and management: A review. Geoderma, 124 (2005), 3-22. DOI: https://doi.org/10.1016/j.geoderma.2004.03.005

[20] HAILE, S. G., NAIR, P. K. R., NAIR, V. D.: 2008. Carbon storage of different soil-size fractions in Florida silvopastoral systems. Journal of Environmental Quality, 27 (2008), 1789-1797. DOI: https://doi.org/10.2134/jeq2007.0509

[21] HAILE, S. G., NAIR, V. D., NAIR, P. K. R.: Contribution of trees to soil carbon sequestration in silvopastoral systems of Florida. Global Change Biology, 16 (2010), 427438. DOI: https://doi.org/10.1111/j.1365-2486.2009.01981.x

[22] KAISER, K., ZECH, W.: 1999. Release of natural organic matter sorbed to oxides and a subsoil. Soil Science Society of America Journal, 63 (1999), 1157-1166. DOI: https:// doi.org/10.2136/sssaj1999.6351157x

[23] EDWARDS, W. M., OWENS, L. B.: Large storm effects on total soil erosion. Journal of Soil and Water Conservation, 46 (1991), 75-78.

[24] SOGBEDJI, J. M., ES, van H. M., YANG, C. L., GEOHRING, L. D., MAGDOFF, F. R.: Nitrate leaching and nitrogen budget as affected by maize nitrogen rate and soil type. Journal of Environmental Quality, 29 (2000), 1813-1820. DOI: https://doi.org/10.2134/ jeq2000.00472425002900060011x

[25] LÓPEZ-DÍAZ, M. L., ROLO, V., MORENO, G.: Trees’ role in nitrogen leaching after organic, mineral fertilization: A greenhouse experiment. Journal of Environmental Quality, 40 (2011), 853-859. DOI: https://doi.org/10.2134/jeq2010.0165

[26] JOSE, S.: Agroforestry for ecosystem services and environmental benefits: An overview. Agroforestry Systems, 76 (2009) 1-10. DOI: https://doi.org/10.1007/s10457-009-9229-7

[27] BAGNOLD, R. A.: Bedload transport in natural rivers. Water Resources Research, 13 (1997), 303-312. DOI: https://doi.org/10.1029/WR013i002p00303

[28] UDAWATTA, R. P., GARRET, H. E., KALLENBACH, R.: Agroforestry buffers for nonpoint source pollution reductions from agricultural watersheds. Journal of Environmental Quality, 40 (2011), 800-806. DOI: https://doi.org/10.2134/jeq2010.0168

[29] 2009. évi XXXVII. törvény az erdőrôl, az erdő védelméről és az erdőgazdálkodásról. (Act No. XXXVII of 2009 on forests, on the protection and management of forests.) 